\title{
The research of cold chain logistics management' effect to the quality of product in China and America
}

\author{
Jing Chen ${ }^{1, a}$, Chao Wang ${ }^{2, b}$ and Ya-hui Jiang ${ }^{3, c}$ \\ ${ }^{1}$ Logistic School, Beijing Wuzi University, Beijing 101149, China \\ ${ }^{2}$ Logistic School, Beijing Wuzi University, Beijing 101149, China \\ ${ }^{3}$ Logistic School, Beijing Wuzi University, Beijing 101149, China \\ a13811480429@126.com, b13811480429@126.com, c1606726143@qq.com
}

\begin{abstract}
Keywords: cold chain management ;the quality of food ;improvement suggestions
Abstract. In recent years, the safety of food gets more and more concentration, the cold chain is very popular in our life, making a big contribution to our country's retail sales.In the supermarket,there are many fresh food and refrigerated food,if a supermarket has a perfect cold chain link, it will guarantee the quality of frozen foods, cold chain management is very important to the food .This article choose China and United States' cold chain link as object and compared the cold chain between two countries,meanwhile, it analyzes the effect of cold chain to the quality of fresh food.
\end{abstract}

\section{Introduction}

In recent years, the cold chain logistics industry developed quickly,consumers' requirement of food quality is growing.In order to face this trend,supermarket chain supermarket must improves their level of cold chain logistics, guaranteeing the quality of product and meeting the demand of the consumers.In order to let consumers buy fresh and high quality products, we must develop the cold chain system.

The purpose of this study is that according to the cold chain logistics present situation in our country, comparing China and the United States from different aspect,founding the link that affect the quality of products in the cold chain logistics,putting forward the corresponding improvement measures,and helps the supermarket develops better.Meanwhile,consumers can buy reassuring food.The significance of this paper is improving the quality of products in business supermarket,ensuring the safety of food, satisfying the shopping needs of consumers, reducing the cost of cold chain,increasing the income of the business supermarket, improving the quality of service and promoting healthy competition.A perfect cold-chain logistics chain should control the temperature processing and the process of transport, Once the fresh food become bad, it will bring great loss to us .Of course ,this is difficult to do well,we should put our efforts to this .No matter what kind of problem we face, we must believe that we can solve them successfully.And our country must pay attention to the cold chain .

\section{The development of cold chain logistics in China and the United States}

\section{China's cold chain logistics}

The source of our food cold chain should be the exports of meat in 1950s.In 1982, China promulgated the law of food health and this is the birth of food cold chain in our country.In 1999, we launched that we should create a green channel,cultivate green market and advocate green consumption. We started to realize the importance of cold chain and we hope to cause less pollution to our environment by using less expense.In order to do that,we are supposed to use technology.

On April 24, 2009,the state council said that we should conduct a plan that adjust our industry.In this plan,we should improve the level of storage ,helping the agricultural products to stay fresh.Then we should improve the cold chain and the level of facilities.From then on,people turned to attach great importance to the logistics of agricultural products.Nowadays,our country's cold chain logistics goal is that setting up a systematic service system and making the fruit and vegetables stay fresh for a long time. This plan helps us promote the development of our country's logistics, and the speed of logistics is 
very rapid.Logistics industry contributes to our country's development, and our government focus on logistics' improvement.Developing cold chain logistics has become a trend.

On July 28, 2010,we developed the cold chain logistics,making the plan's aim become more clear.More and more people realized the importance of the cold chain logistics. And there are more companies want to develop the cold chain logistics and the third party logistics appeared.

\section{American cold chain logistics}

The cold chain logistics started in the 19th century, and in this century, the refrigerator appeared. After that ,there are many food being placed in refrigerator.Because the refrigerator can guarantee the quality of food effectively.In the 1930 s, the U.S established a food cold chain system. In the $40 \mathrm{~s}$, the second word war broke out,causing the cold chain logistics destroyed in Europe. After the war, the cold chain logistics was rebuilt soon. There are four pieces of historical events about the cold chain in the United States has a great influence to the world ,just as following.

In 1943, the world food logistics organization (WFLO) was established. As a science foundation, the world food logistics organization researched the food and their storage.It tell us that we should use technology to storage the food scientifically .Nowadays, the science developed quickly,we are supposed to learn more knowledge to improve ourselves. And the company should cooperate with the government and some private organizations to promote scientific research.Developing cold storage refrigeration and training staff is need .Setting up cold chain industry is useful to improve the cold chain, which be used to test the transportation, handling, storage reliability and the quality of perishable goods.

Now,America has possessed advanced technology of cold chain and has formed an integrated system.

\section{The safety of food in cold chain}

When we go shopping,the quality of the product has a great impact to consumers .If we think that the quality ,we will buy them. The cold chain's aim is to guarantee the quality of food.In America, they possess a high level of logistics , and the quality of food is better than our country's. Our country's cold chain logistics process is not perfect,and there are many problems.Many research show these problems. The cold chain has bring great loss to our country's economic.

A perfect cold-chain logistics chain should control the temperature processing and the process of transport, Once the fresh food become bad, it will bring great loss to us .Of course, this is difficult to do well,we should put our efforts to this .No matter what kind of problem we face, we must believe that we can solve them successfully. And our country must pay attention to the cold chain .

We can see that a complete cold chain logistics plays an important role in the logistics process, and the cold-chain logistics can guarantee the quality of food, it will bring great benefit to our country. We are supposed to consider our actual situation. With the development of economic,the demand of cold fresh food is greatly increased. Cold chain logistics market has great potential. There many things that we can do to improve the current cold chain conditions

\section{The United States' entire cold chain}

The United States is the largest developed country, its cold chain logistics is also very perfect. The United States has a very perfect cold chain logistics system. It guarantee the quality of food .There are some reasons.

(1) The cost of cold chain logistics is high

The consciousness of cold chain logistics is very strong. In the United States, people mainly buy fresh food, which promoting the use of cold chain. And the proportion of cold chain logistics system is about $80 \%$ to $90 \%$.

(2) The technology level of cold chain

The key to cold chain logistics technology is low temperature. The United States has a very advanced cold-chain logistics technology. And they attache great importance to the quality of product . 
The fruits are stored in the refrigerator,they use advanced technology to inhibit the respiration of fruit and vegetables.

(3) The improvement of facilities

The cold chain logistics' equipment is very well, such as refrigerator . The way of transport includes highway and railway and and so on. They use them to transport the vegetables and fruits. The volume of cold storage is very big.

(4) The system of cold chain logistics

The cold chain logistics system in United States is better than China's.And the control of temperature is very well. Thy has a systematic process of cold chain logistics. In the cold chain , the control of temperature is important. The control of temperature guarantees the quality of fresh food .

\section{The gap of cold chain logistics in China}

\section{The comparison of cold chain logistics' consciousness and transport rate}

In China, the awareness of using cold chain is not very strong. A lot of people reckon that the fresh food doesn't need cold chain. As long as the smell is good,we think that the food is good .If the food doesn't possess a improper storage, it will lose many nutrients, and is not good to our health.

The ratio of using cold chain in China is very low, the proportion of vegetable is $5 \%$, the proportion of meat was $15 \%$, the proportion of aquatic products was $23 \%$. These data can show that the amount of using cold chain is very low. There are a lot of vegetables and fruits are placed at room temperature.

In addition, $90 \%$ of China's cold storage and refrigeration truck is used to storage the frozen food . In winter ,there are many cold warehouse that will be idle,causing the waste of energy.But in America, there are only $30 \%$ of the refrigerator is in the service,so it will cause this problem.Compared with the United States, we found that our country's cold chain logistics is mainly used for frozen frozen food.

\section{The comparison of cold chain logistics' infrastructure and facilities}

In the study of the contrast of cold chain logistics in China and the United States, we found that the cold chain logistics in USA is very different from China'.In fact, in most of articles, we analyzed the current situation of China's cold chain logistics, there are many problems , and in order to let the logistics in China developed better,we should try our best to do that.All in all, the United States has many successful experiences in the development of cold chain logistics, but we can't completely use their experience,we must think about our country's level.The two countries' national condition is different.What we can do is learning their experience. We are supposed to consider our actual situation. With the development of economic,the demand of cold fresh food is greatly increased. Cold chain logistics market has great potential. There many things that we can do to improve the current cold chain conditions.

We can see that a complete cold chain logistics plays an important role in the logistics process, and the cold-chain logistics can guarantee the quality of food, it will bring great benefit to our country. We are supposed to consider our actual situation. With the development of economic, the demand of cold fresh food is greatly increased. Cold chain logistics market has great potential. There many things that we can do to improve the current cold chain conditions.

\section{References}

[1]Min Kuang, The think of cold chain logistics development in our country[J],Railway transportation and economy,2010,(03):59-62.

[2]Qianli Dong,Functional logistics[M].Da Lian:Northeast university of finance and economics press,2009.

[3]Lu Sun,Food industry chain integration research[D],Cheng Du:Transportation planning and management,2009. 
[4]Xiaolin He,Li Sun,Xiaojing Zhang,Bottleneck analysis of cold chain logistics development in our country and the broken neck[J], Value engineering,2014,18:26-27.

[5]Logistics industry adjustment and revitalization plan[EB/OL], The Chinese government network.2009-4.

[6]QiZhao, Talking about the cold chain logistics[J], The international market,2007(03):68-69.

[7]Zhusheng Xu,Supermarket chain in our country have some samples of cold-chain logistics problems and countermeasures $[\mathrm{J}]$.Entrepreneurs.

2013,09:24-25.

[8]Ruihong Huang,The United States seen refrigerator[J],Cold storage technology,1984,04:47-52.

[9]Mozhi Li, The cold chain logistics distribution path optimization research area retail chain[D], Taiyuan university of technology,2012.

[10]Hongxia Guo,Ming Shao,Process Reengineering of Cold ChainLogistics ofAgricultural Products Based on Low-carbon Economy. Asian Agricultural Research 2012,4(2): 59-62. 